Article

\title{
Bisdemethoxycurcumin Induces Cell Apoptosis and Inhibits Human Brain Glioblastoma GBM 8401/Luc2 Cell Xenograft Tumor in Subcutaneous Nude Mice In Vivo
}

\author{
Te-Chun Hsia ${ }^{1,2}$, Shu-Fen Peng ${ }^{3,4}$, Fu-Shin Chueh ${ }^{5}$, Kung-Wen Lu ${ }^{6}$, Jiun-Long Yang ${ }^{7}$, An-Cheng Huang ${ }^{7} \mathbb{D}$, \\ Fei-Ting Hsu $4, *,+$ and Rick Sai-Chuen $\mathrm{Wu}^{8,9, *,+}$
}

\section{check for} updates

Citation: Hsia, T.-C.; Peng, S.-F.; Chueh, F.-S.; Lu, K.-W.; Yang, J.-L.; Huang, A.-C.; Hsu, F.-T.; Wu, R.S.-C. Bisdemethoxycurcumin Induces Cell Apoptosis and Inhibits Human Brain Glioblastoma GBM 8401/Luc2 Cell Xenograft Tumor in Subcutaneous Nude Mice In Vivo. Int. J. Mol. Sci. 2022, 23, 538. https://doi.org/ 10.3390/ijms23010538

Academic Editor: Sabrina Battista

Received: 29 November 2021 Accepted: 30 December 2021 Published: 4 January 2022

Publisher's Note: MDPI stays neutral with regard to jurisdictional claims in published maps and institutional affiliations.

Copyright: (C) 2022 by the authors. Licensee MDPI, Basel, Switzerland. This article is an open access article distributed under the terms and conditions of the Creative Commons Attribution (CC BY) license (https:// creativecommons.org/licenses/by/ $4.0 /)$.
1 Department of Respiratory Therapy, China Medical University, Taichung 406, Taiwan; D1914@mail.cmuh.org.tw

2 Department of Internal Medicine, China Medical University Hospital, Taichung 404, Taiwan

3 Department of Medical Research, China Medical University Hospital, Taichung 404, Taiwan; t20811@mail.cmuh.org.tw

4 Department of Biological Science and Technology, China Medical University, Taichung 406, Taiwan

5 Department of Food Nutrition and Health Biotechnology, Asia University, Taichung 413, Taiwan; fushin@asia.edu.tw

6 School of Post-Baccalaureate Chinese Medicine, College of Chinese Medicine, China Medical University, Taichung 406, Taiwan; prorna@mail.cmu.edu.tw

7 Department of Nursing, St. Mary's Junior College of Medicine, Nursing and Management, Yilan 266, Taiwan; yangjiunlong@gmail.com (J.-L.Y.); haj@smc.edu.tw (A.-C.H.)

8 Department of Anesthesiology, China Medical University Hospital, Taichung 404, Taiwan

9 Department of Anesthesiology, China Medical University, Taichung 404, Taiwan

* Correspondence: sakiro920@mail.cmu.edu.tw (F.-T.H.); rickwu@mail.cmuh.org.tw (R.S.-C.W.); Tel.: +886-4-2205-3366 (ext. 2532) (F.-T.H.); +886-4-2205-2121 (ext. 5242) (R.S.-C.W.); Fax: +886-4-2205-3764 (F.-T.H.); +886-4-2205-2121 (ext. 5237) (R.S.-C.W.)

+ These authors contributed equally to this work.

Abstract: Bisdemethoxycurcumin (BDMC) has biological activities, including anticancer effects in vitro; however, its anticancer effects in human glioblastoma (GBM) cells have not been examined yet. This study aimed to evaluate the tumor inhibitory effect and molecular mechanism of BDMC on human GBM 8401/luc2 cells in vitro and in vivo. In vitro studies have shown that BDMC significantly reduced cell viability and induced cell apoptosis in GBM 8401/luc2 cells. Furthermore, BDMC induced apoptosis via inhibited Bcl-2 (anti-apoptotic protein) and increased Bax (pro-apoptotic proteins) and cytochrome c release in GBM 8401/luc2 cells in vitro. Then, twelve BALB/c-nude mice were xenografted with human glioblastoma GBM 8401/luc2 cancer cells subcutaneously, and the xenograft nude mice were treated without and with BDMC (30 and $60 \mathrm{mg} / \mathrm{kg}$ of BDMC treatment) every 3 days. GBM 8401/luc2 cell xenografts experiment showed that the growth of the tumors was significantly suppressed by BDMC administration at both doses based on the reduction of tumor size and weights. BDMC did not change the body weight and the H\&E histopathology analysis of liver samples, indicating that BDMC did not induce systemic toxicity. Meanwhile, treatment with BDMC up-regulated the expressions of BAX and cleaved caspase-3, while it down-regulated the protein expressions of Bcl-2 and XIAP in the tumor tissues compared with the control group. This study has demonstrated that BDMC presents potent anticancer activity on the human glioblastoma GBM $8401 /$ luc2 cell xenograft model by inducing apoptosis and inhibiting tumor cell proliferation and shows the potential for further development to the anti-GBM cancer drug.

Keywords: BDMC; glioblastoma (GBM) 8401/luc2 cells; apoptosis; xenograft; BAX; Bcl-2

\section{Introduction}

Glioblastoma (GBM) in adults and medulloblastoma and pineoblastoma in children are aggressive brain tumors. GBM is the fatal form of malignant, lethal primary astrocytic, and 
a highly angiogenic brain tumor in humans' central nervous system. It accounts for $12-15 \%$ of all intracranial tumors and $50-60 \%$ of all primary brain tumors [1,2]. The treatment of GBM is still unsatisfied due to its aggressiveness with poor prognosis, with a median survival of 14.6 months from diagnosis [3,4]. Treatments of GBM usually include radiotherapy alongside surgical resection and combined with chemotherapy such as temozolomide (TMZ), which is the landmark treatment protocol [5]. However, radiotherapy-induced alterations in the brain microenvironment may result in GBM recurrence and aggressiveness [6]. The survival rate for patients with glioblastoma remains dismal, and around $>75 \%$ of GBM patients treated with TMZ succumb within 2 years due to relapse [7], and it also often triggers significant long-term debilitating side effects in survivors. Thus, finging a new compound for reducing side effects on GBM patients is urgent.

Many plant-based phytochemicals have been considered to be associated with human health, and they have even proved to reduce the risk of certain types of cancer [8-12]. Curcuminoids are natural and polyphenol coloring compounds derived from Curcuma longa Linn, which is also an edible plant. Curcuminoids contain three major bioactive ingredients: curcumin, demethoxycurcumin (DMC), and bisdemethoxycurcumin (BDMC), at a ratio of 77:17:3 [13]. The curcuminoids in the turmeric acetone extract are crucial for the gastroprotective effect against ethanol-induced damage [14]. BDMC prevented kidney fibrosis by activating fibroblast apoptosis [15] and promoted apoptosis in human platelets via activation of ERK signaling pathway [16]. It induced cell apoptosis in liver cancer Hep 3B cells [17] and induced caspase-dependent and -independent apoptosis via Smad or Akt signaling pathways in osteosarcoma HOS cells [18]. Furthermore, BDMC possessed favorable cardioprotection in an Nrf2/HO-1-dependent manner and activated the expression of Nrf2/HO-1 via PI3K/AKT signaling [19]. It also suppressed adipogenesis in 3T3-L1 adipocytes and prevented high-fat diet-induced obesity in mice [20]. Besides, BDMC attenuates cisplatin-induced renal injury through anti-apoptosis in renal tubular epithelial cells in vitro and protective effect on cisplatin-induced kidney injury in mice [21]. It was reported that oral treatment with micellar BDMC led to quantifiable concentrations of BDMC in glioblastoma patients that may alter intratumoral energy metabolism [22]. Recently, we combined all-trans retinoic acid (ATRA) with BDMC to treat human liver cancer Hep 3B cells, and the results led to increasing apoptotic cell death than that of ATRA or BDMC treatment only in vitro [17].

Although many studies have shown BDMC induced apoptotic cell death in many human cancer cells; however, there are no reports to show BDMC reduced brain tumor cells in the animal model in vivo. Therefore, in the present study, we used human glioblastoma GBM 8401 cell xenograft mice, and then the animals were treated with BDMC. We are the first to show BDMC suppressed tumor growth of GBM 8401 cell xenograft nude mice in vivo. These findings offer more information on $\mathrm{BDMC}$, which may further consideration for future use in glioblastoma patients.

\section{Results}

2.1. BDMC Reduced Cell Viability, Induced Apoptosis, and Affected Apoptosis-Associated Proteins in GBM 8401/luc2 Cells

MTT assay was used to measure cell cytotoxicity, and flow cytometer was used to assay cell apoptosis. After, GBM 8401/luc2 cells were treated with various concentrations of BDMC for $48 \mathrm{~h}$ and cells assayed cell cytotoxicity and apoptosis, and results are shown in Figure $1 \mathrm{~A}, \mathrm{~B}$, which demonstrates that BDMC suppressed total viable cell number and the inhibitory rate was dose-dependently increased following BDMC treatment $(p<0.05)$. As presented in Figure 1A, after $48 \mathrm{~h}$ treatment, GBM 8401/luc2 cell population was inhibited at 17.36-95.60\% with 15-50 $\mathrm{MM}$ BDMC. Annexin V was used to quantify GBM 8401/luc2 cell apoptosis after BDMC treatment, and results are shown in Figure 1B. After 48 h, BDMC treatment dose-dependently increased the cell apoptosis about 3-19 fold; thus, the cell apoptosis was significantly increased after treatment with BDMC compared with the control $(p<0.05)$. Cells were pretreated with or without Z-DEVD-FMK (caspase-3 inhibitor) or in- 
hibitor of mitochondria membrane potential (cyclosporin A) and were treated with 0 and 25 $\mu \mathrm{M}$ of BDMC for $48 \mathrm{~h}$. Cell proliferation was measured, and results were presented in Figure $1 C, D$. Figure $1 C$ indicated that cells that were pretreated with Z-DEVD-FMK and then treated with BDMC experienced significantly increased cell proliferation up to $26 \%$ when compared to BDMC treatment alone. Results from Figure 1D also showed that cells were pretreated with cyclosporin A and then treated with BDMC significantly increased cell proliferation up to $14 \%$ when compared to BDMC treatment alone. Furthermore, BDMC decreased cell numbers and induced apoptosis were involved in apoptosis-associated protein, and cells were pretreated with or without Z-DEVD-FMK or cyclosporin A and then treated with 0 and $25 \mu \mathrm{M}$ of BDMC for $48 \mathrm{~h}$. Apoptosis-associated proteins were measured by western blotting, and results are presented in Figure 1E,F. Figure 1E indicates that the pretreatment of Z-DEVD-FMK and treated with BDMC led to an increase of pro-caspase-3 and decrease of active-caspase- 3 when compared to BDMC treated only. Figure $1 \mathrm{~F}$ indicates that the pretreatment of cyclosporine $\mathrm{A}$ and treated with BDMC led to an increase of $\mathrm{Bcl}-2$ and decrease of Bax, cytochrome $\mathrm{c}$ and AIF when compared to BDMC treated only. Based on both results, BDMC induced cell apoptosis via affected apoptosis-associated proteins in GBM 8401/luc2 cells

A.

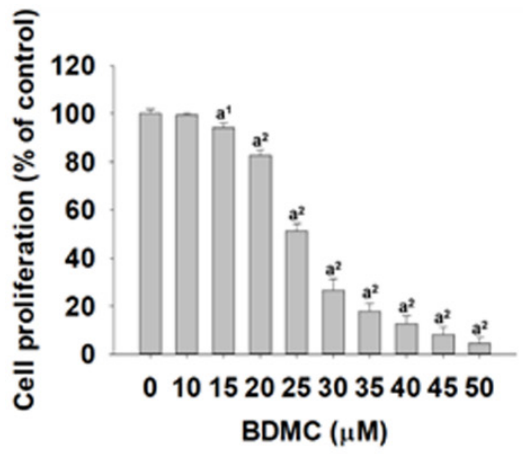

D.

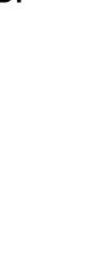

B.

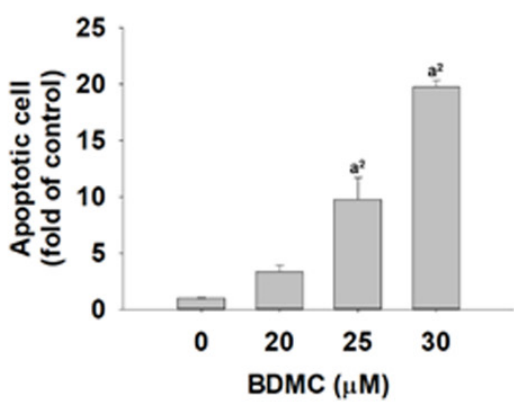

C.

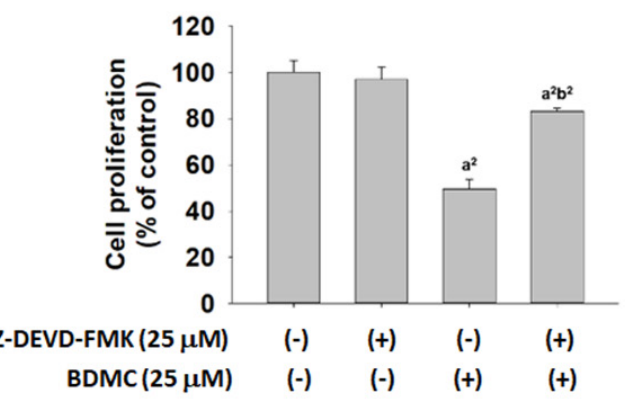

E.

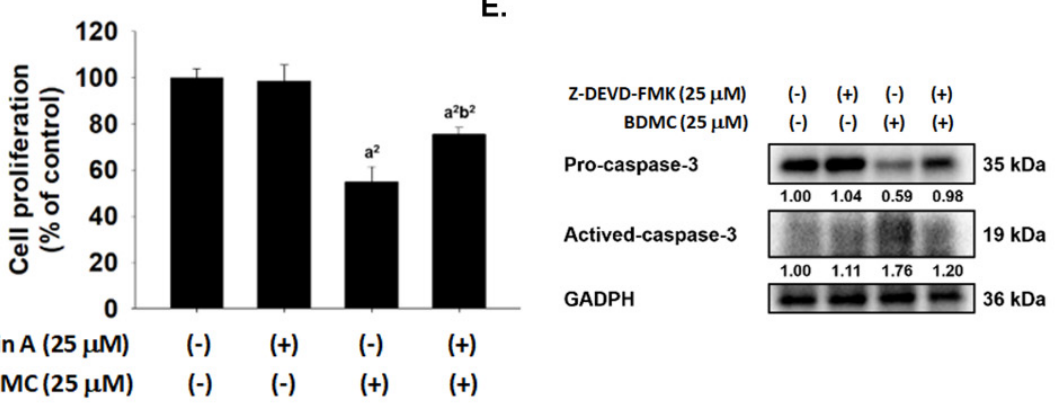

F.

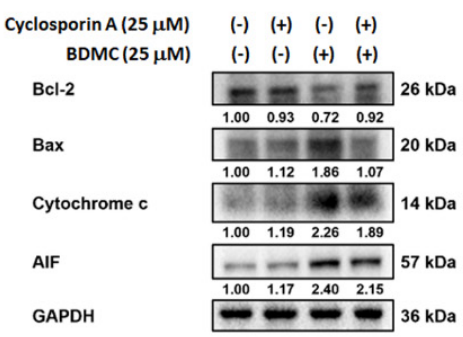

Figure 1. BDMC induced cytotoxic effect and cell apoptosis and affected apoptosis-associated protein expression in GBM 8401/luc2 cells. Cells were placed in cell plates at the final density of $1 \times 10^{5}$ cells $/ \mathrm{mL}$ for $48 \mathrm{~h}$, and cells were treated with $0,10,15,20,25,30,35,40,45$, and $50 \mu \mathrm{M}$ of $\mathrm{BDMC}$ for $48 \mathrm{~h}$. After treatment, cells were harvested from each well for measuring cell proliferation (A) and apoptosis (B). Cells were pretreated with Z-DEVD-FMK (caspase-3 inhibitor) (C) and inhibitor of mitochondria membrane potential (cyclosporin A) (D) and were treated with 0 and $25 \mu \mathrm{M}$ of $\mathrm{BDMC}$ for $48 \mathrm{~h}$ and cell proliferation were determined. Cells were harvested for examining apoptosisassociated protein expression $(\mathbf{E}, \mathbf{F})$ by western blotting as described in Materials and methods. $\mathrm{a}^{1}$ and $\mathrm{a}^{2}$ significantly different at $p<0.05$ and $p<0.01 \mathrm{vs}$. the control group. $\mathrm{b}^{2}$ significantly different at $p<0.01$ vs. the BDMC group. 


\subsection{Flow Chart of In Vivo Experiments}

The overall design of the experiments is presented in Figure 2, which shows the ingestion of GBM 8401/luc2 cells and the treatment of BDMC and sacrificed animals.

\section{Subcutaneous injection GBM8401/luc2 $\left(1 \times 10^{7}\right)$}

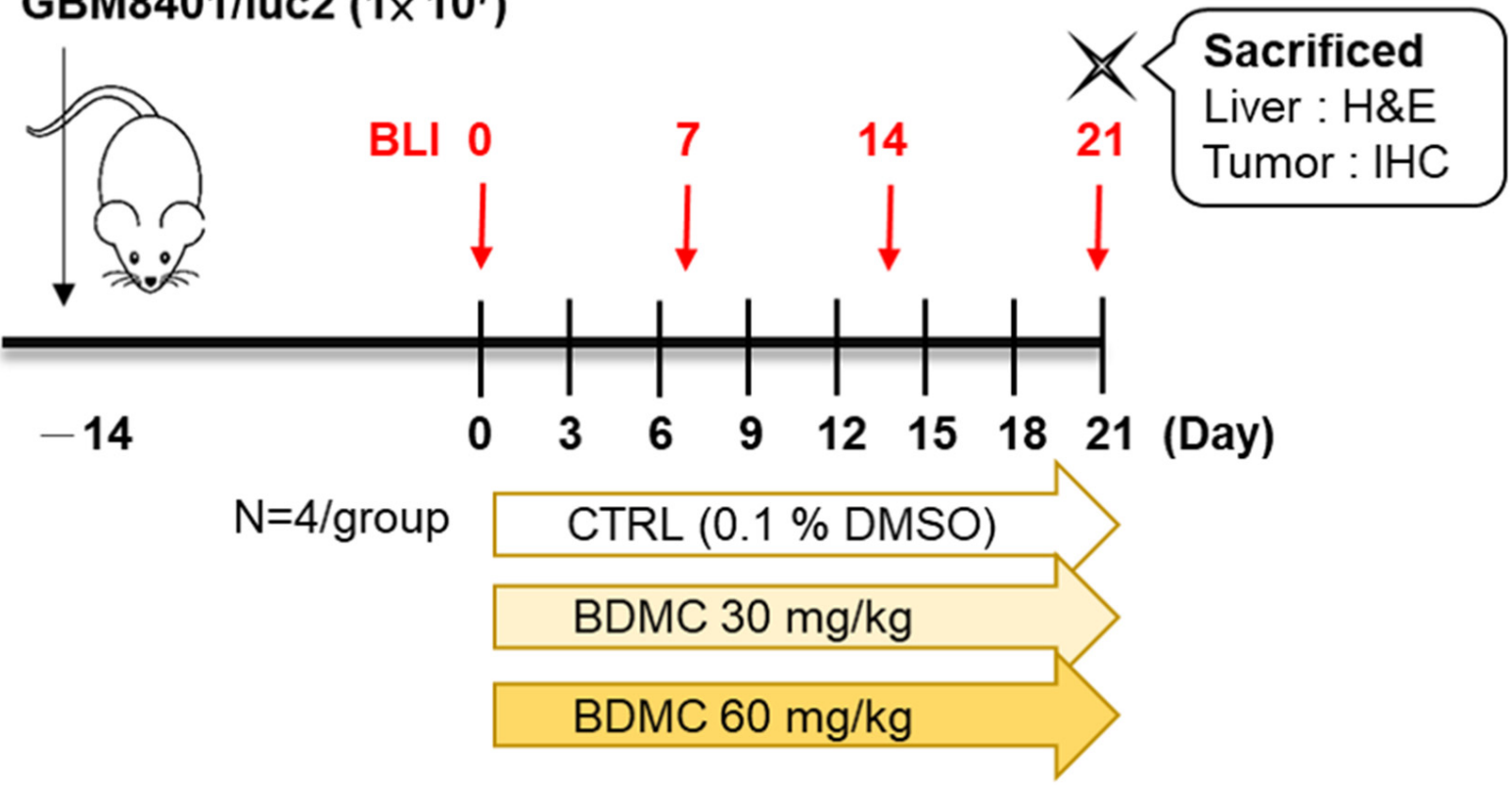

Figure 2. The flow chart for BDMC treatment in athymic BALB/c nu/nu nude mice after inoculation with GBM 8401/luc2 cells. Twelve mice were inoculated subcutaneously with GBM 8401/luc2 cells. Mice were randomly divided into three groups for treatment every day. Group I $(n=4)$ was treated $0.1 \%$ DMSO in $100 \mu \mathrm{L}$ of DDW. Group II $(n=4)$ was treated with BDMC (30 mg/kg). Group III $(n=4)$ was treated with BDMC $(60 \mathrm{mg} / \mathrm{kg})$. Each mouse was treated by gavage for 21 days; the body weight and tumor size were recorded every 3 days, and bioluminescent imaging was performed every week, as described in the Materials and Methods.

2.3. BDMC Did Not Affect the Body Weight and Liver Pathology of Athymic BLAB/c nu/nu Nude Mice Bearing GBM 8401/luc2-Derived Tumors

The results shown in Figure 3A indicate that treatment with BDMC at 30 and $60 \mathrm{mg} / \mathrm{kg}$ did not lead to liver pathology change as compared to the control group. Besides, in Figure 3B, no statistically significant differences in body weight of mice were found in the treated or control group. These results suggested that BDMC may not induce general toxicity of mice, including acute or delayed toxicity.

2.4. BDMC Inhibited GBM 8401/luc2 Cell Xenograft Tumor Growth in Nude Mice Bearing GBM 8401/luc2-Derived Tumors

Mice treated with $60 \mathrm{mg} / \mathrm{kg}$ BDMC exhibited significantly smaller tumor volume at day $6(p<0.05)$ and day 9-21 $(p<0.01)$ after the first treatment (Figure 4A). The representative tumor photographs with or without BDMC treatment were shown in Figure 4B, which indicated that BDMC treatment reduced the tumor size when compared to the control group. The higher dose of BDMC $(60 \mathrm{mg} / \mathrm{kg})$ has significantly reduced tumor weights than that of lower dose of BDMC $(30 \mathrm{mg} / \mathrm{kg})(p<0.01)$ (Figure $4 \mathrm{C})$. Taken together, BDMC showed the potential to inhibit tumor growth on glioblastoma bearing animal models. 
A.

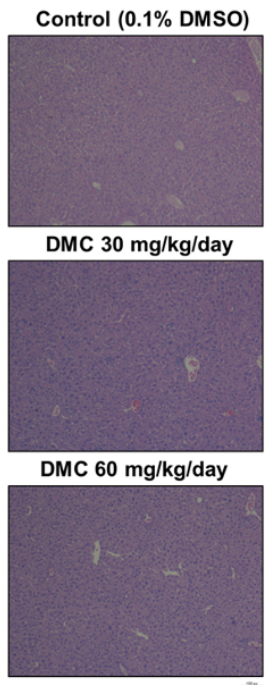

B.

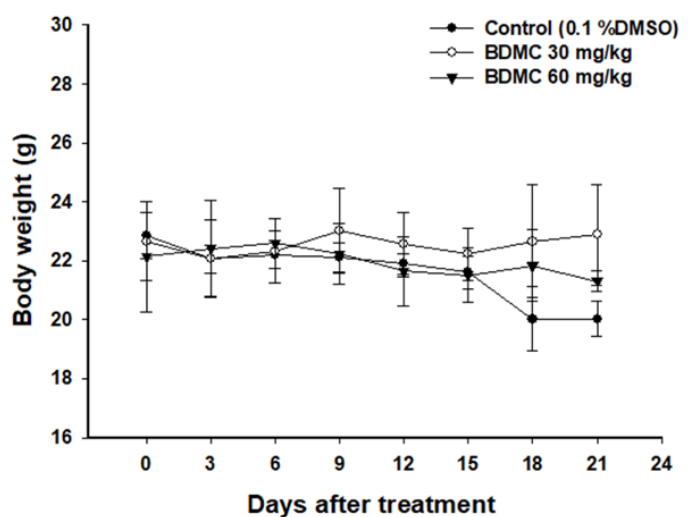

Figure 3. Liver $\mathrm{H \& E}$ staining and body weights of athymic BALB/c nu/nu nude mice after inoculation with GBM 8401/luc2 cells. (A) Bright view microscope image of liver H\&E staining from each group $(\times 100)$. (B) Mouse body weight was measured by digital balance every 3 days.

A.

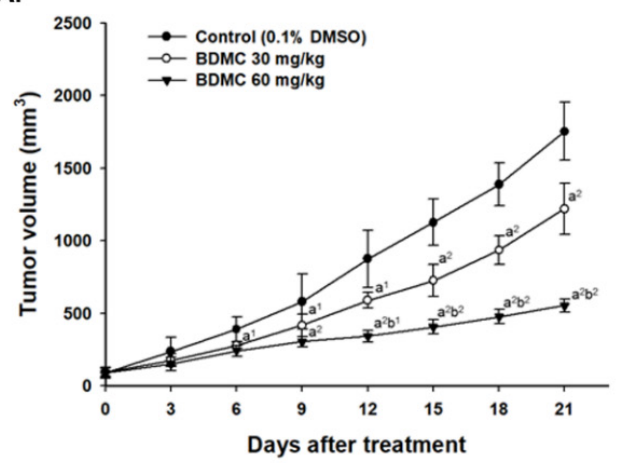

B.

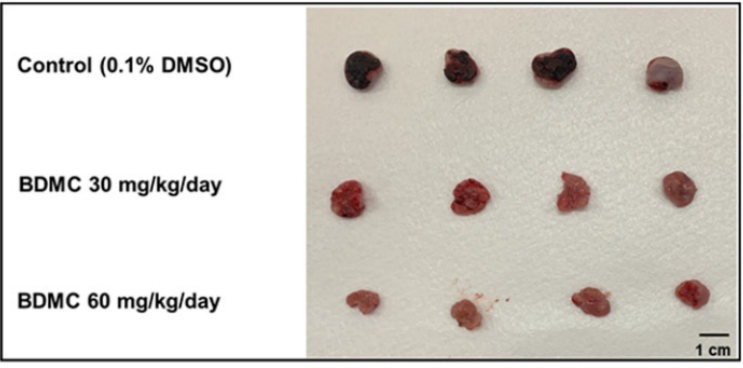

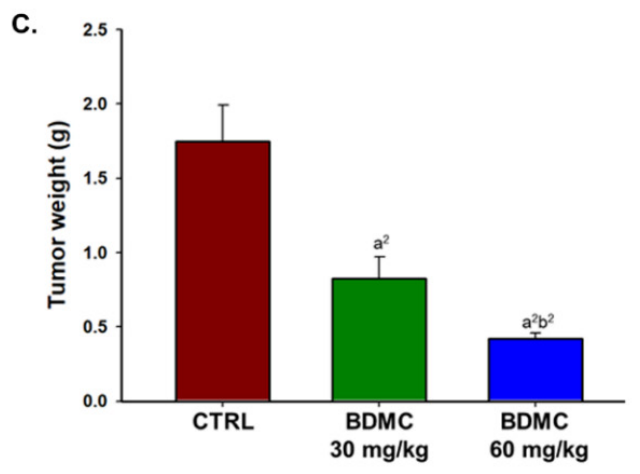

Figure 4. BDMC reduces GBM 8401/luc2 cell xenograft tumor growth in athymic BALB/c nu/nu nude mice. After GBM 8401/luc2 tumor-bearing mice were generated, mice were treated with DDW ( $0.1 \%$ DMSO) or BDMC (30 and $60 \mathrm{mg} / \mathrm{kg}$ ) every three days. (A) The tumor volume of each mouse was measured every three days. (B) Images of representative mice tumors from each group. After mice were anesthetized with overdose isoflurane $(>3 \%)$, they were sacrificed, and the final tumor weights were measured as described in the Materials and Methods. (C) Quantification results of mouse tumors weight from each group. $\mathrm{a}^{1}$ and $\mathrm{a}^{2}$ significantly differ at $p<0.05$ and $p<0.01 \mathrm{vs}$. the control group. $\mathrm{b}^{1}$ and $\mathrm{b}^{2}$ significantly differ at $p<0.05$ and $p<0.01 \mathrm{vs}$. the BDMC $30 \mathrm{mg} / \mathrm{kg}$ group. 


\subsection{BDMC Reduced Living Cell Signal of Nude Mice Bearing GBM 8401/luc2-Derived Tumors}

To further investigate whether tumor growth inhibition was correlated to reduce the living cell population within the tumor, we performed the scanning of CMV-derived luc2 reporter gene on GBM-8401/luc2-bearing tumor mice. As shown in BLI results from each group of mice, a relatively cold signal was found in the BDMC-treated groups on the colorcoded map (Figure 5A). The luc 2 reporter gene intensity on the tumor was measured every week and quantified by Living Image software (v2.2). The total photon flux of the control group was two to four times more than that of BDMC-treated mice (Figure 5B). Significant living cell signal suppression was found in the higher dosage of the BDMC-treated group since day 7. In sum, BDMC treatment may reduce the living cell population within the tumor area.

A.

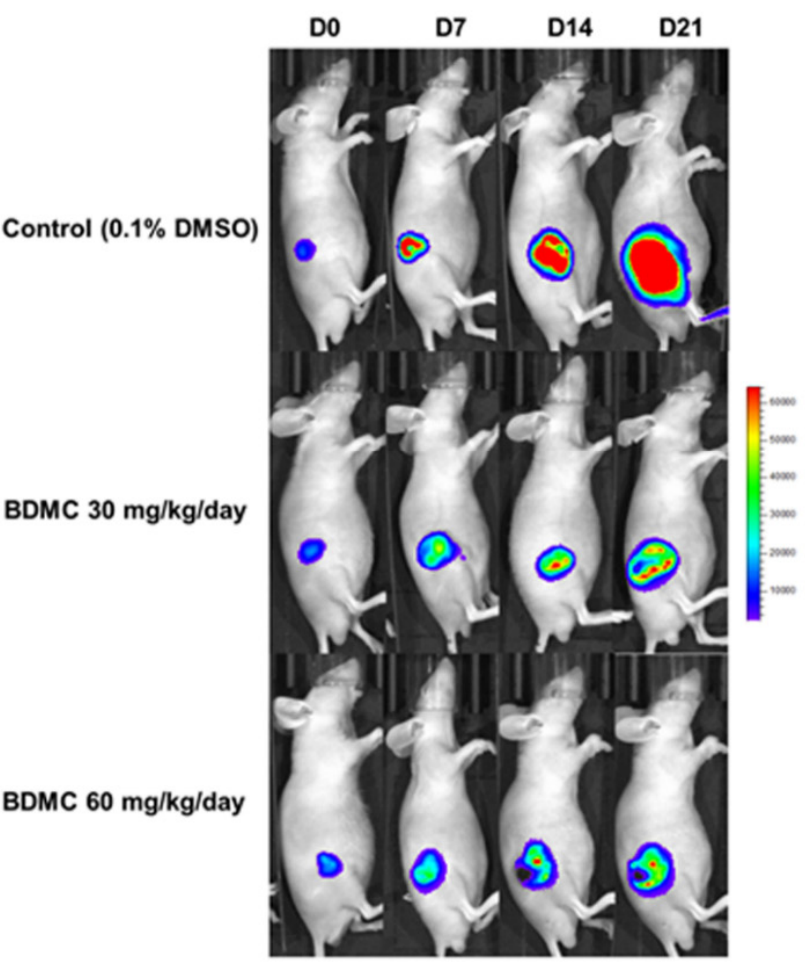

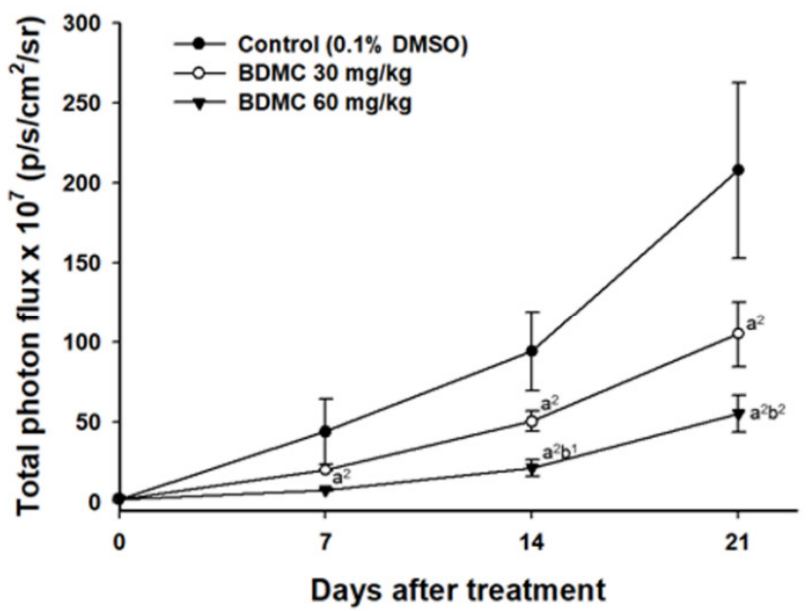

Figure 5. Luc2 signals from living tumor cells were suppressed by BDMC treatment. (A) The representative BLI results from each group at different time points. (B) Quantification results of $l u c 2$ signal intensity of tumors. ( $\mathrm{a}^{2} p<0.01$ vs. control; $\mathrm{b}^{1} p<0.05$ and $\mathrm{b}^{2} p<0.01 \mathrm{vs.} \mathrm{BDMC} 30 \mathrm{mg} / \mathrm{kg}$ ).

2.6. BDMC Affects the Expression of Apoptosis-Related Protein Signal Pathway of Nude Mice Bearing GBM 8401/luc2-Derived Tumors

To fully evaluate the tumor inhibition mechanism of BDMC treatment on GBM $8401 /$ luc2 cell xenografts, tumors were collected from each animal to examine the expression of the apoptosis-associated protein by IHC staining. Results indicated that BDMC decreased the levels of Bcl-2 and XIAP (Figure 6A,B) and increased that of cleaved caspase-3 and BAX (Figure 6C,D). Overall, these data demonstrated that BDMC suppressed tumor properties in vivo via activation of apoptosis signaling. 
A.
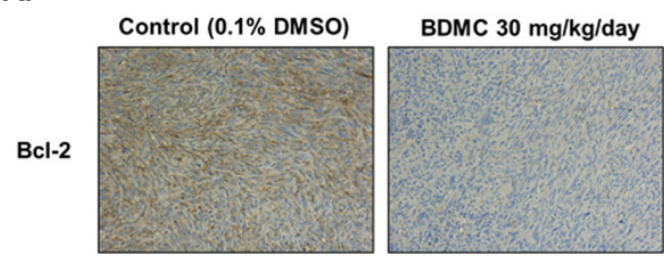

XIAP
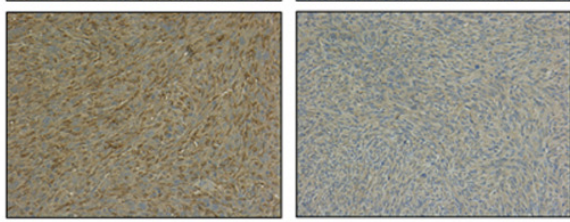

C.

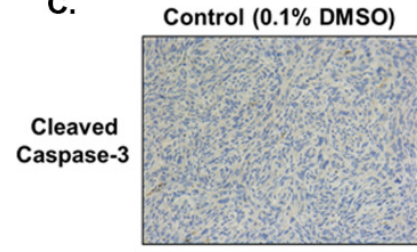

BAX

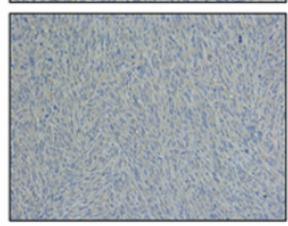

BDMC $60 \mathrm{mg} / \mathrm{kg} /$ day
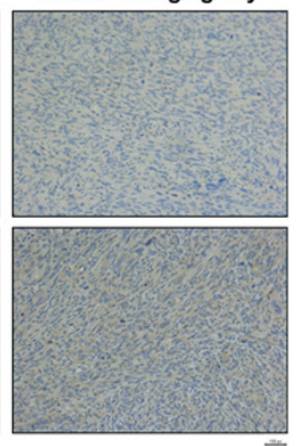

BDMC $60 \mathrm{mg} / \mathrm{kg} /$ day
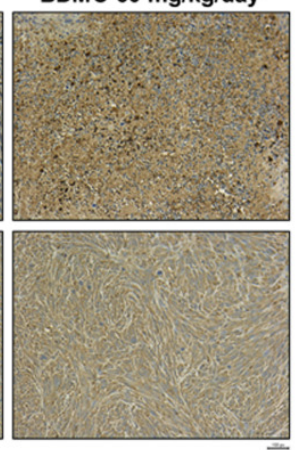

B.

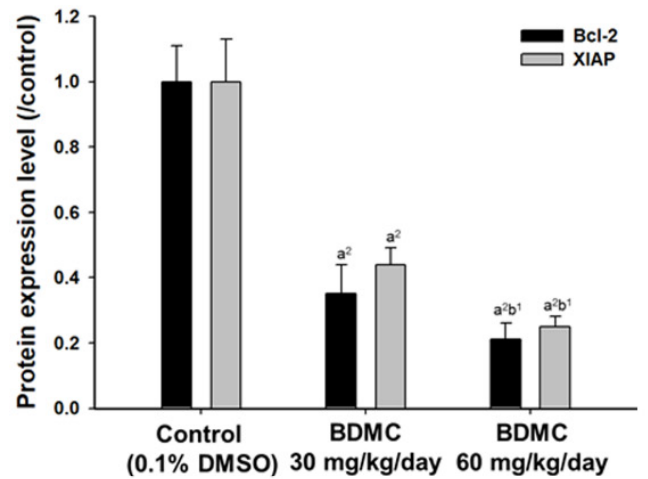

D.

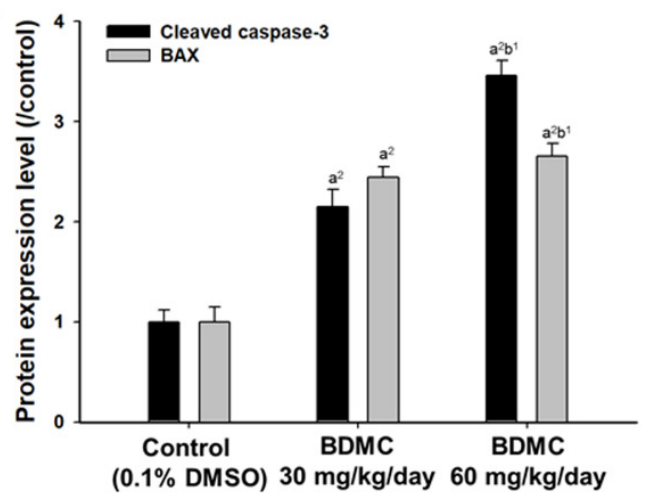

Figure 6. BDMC affects the expression of apoptosis-related proteins in GBM 8401/luc2 cell xenografts. After treatment, tumors were isolated from GBM 8401/luc2 xenografts, and IHC staining was performed as described in the Materials and Methods for Bcl-2 apoptosis regulator (Bcl-2) and Xlinked inhibitor of apoptosis protein (XIAP) (A) and their levels of proteins (B); cleaved caspase-3 and Bcl-2-associated X (BAX) (C) and their levels of proteins (D). $\mathrm{a}^{2}$ significantly different at $p<0.01$ vs. the control group. $\mathrm{b}^{1}$ significantly different at $p<0.05 \mathrm{vs}$. the BDMC $30 \mathrm{mg} / \mathrm{kg}$ group. Light brown color means the low expression of proteins and heavier brown colors means higher expression of proteins.

\subsection{BDMC Effectively Triggers the Apoptosis Mechanism and Suppressed Glioblastoma Tumor Growth}

Both Bcl-2 apoptosis regulator (Bcl-2) and X-linked inhibitor of apoptosis protein (XIAP) were recognized as anti-apoptosis factors that contribute to tumor progression, while Bcl-2-associated $X(B A X)$ and caspase-3 were known as apoptosis markers. In Figure 7, we demonstrated the potential mechanism for BDMC-induced inhibition of tumor progression is through blockage of $\mathrm{Bcl}-2$ and XIAP and the promotion of BAX and caspase-3 cleavage in vivo. 


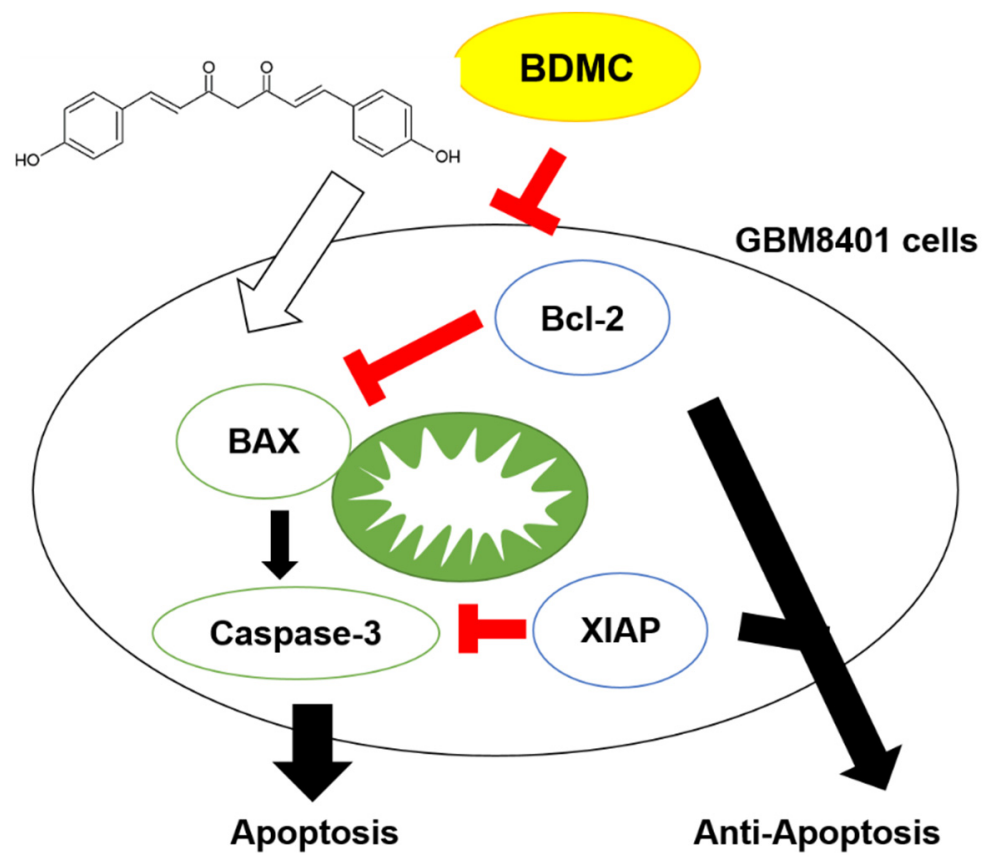

Figure 7. The mechanisms involved in inhibiting tumor growth upon BDMC treatment.

\section{Discussion}

Currently, the standard therapy for high-grade glioblastomas (HGGs) (one of the most aggressive malignant primary brain tumors) such as GBM is radiotherapy [23], but the radio-resistance during the course of irradiation is one of the efficacy limitations [24,25]. The majority of HGGs eventually recur; thus, there are no effective treatments for this population. Therefore, intensive research and development of alternative effective anticancer drugs for patients with GBM is critical and needed [26].

Recently, studies have focused on pursuing a new therapeutic target in solid tumors, and this target is associated with poor survival among GBM patients [27-29]. Many plantderived products (such as paclitaxel, vinblastine, and etoposide) and their derivatives have been recognized to be a standard repertoire of cancer chemotherapy [30]. Recently, it was reported that BDMC inhibited cell proliferation and induced cell apoptosis of GBM 8401 cells [31]; however, there are no reports to show BDMC how affected apoptosis-associated protein expression and affected the tumor growth of GBM 8401 cells in vivo. Therefore, we further investigated BDMC-induced cell apoptosis and affected apoptosis-associated protein expression, furthermore, to investigate the effects of BDMC on the tumor growth of GBM 8401 cells in subcutaneous nude mice in vivo.

In the present study, we investigated the cytotoxic effects of BDMC on GBM 8401/luc2 cells in vitro, and results show that BDMC reduced total cell viability (Figure 1A) and induced cell apoptosis (Figure 1B) of GBM 8401/luc2 cells, and that these effects were dosedependent. These findings are in agreement with BDMC-induced cytotoxic effects and induced cell apoptosis in GBM 8401 cells [31]. However, apoptosis-associated protein expression, whether or not it was involved in BDMC-induced apoptosis in GBM 8401 cells are not available. Furthermore, it is well known that cell apoptosis may occur through caspase3 or mitochondria dependently; thus, we also investigated BDMC regarding whether or not it affected caspase- 3 or cytochrome c release in GBM 8401/luc2 cells. Currently, results also showed that BDMC induced cell apoptosis via caspase- 3 and mitochondria based on the co-treatment of Z-DEVD-FMK (caspase-3 inhibitor) or inhibitor of mitochondria membrane potential (cyclosporin A) and 0 and $25 \mu \mathrm{M}$ of BDMC, leading to an increase of cell viability when compared to BDMC treated alone (Figure 1C,D). Moreover, the results (Figure 1E,F) from western blotting also indicated that BDMC decreased anti-apoptotic protein Bcl-2, increased pro-apoptotic protein BAX, and increased cytochrome $\mathrm{c}$ and AIF release in GBM $8401 /$ luc2 cells in vitro. 
There are no reports to show BDMC inhibits tumor growth of GBM 8401/luc2 cells in vivo; therefore, the primary purpose of this study is to evaluate the inhibition of tumor growth of BDMC in the animal model by different doses, times, and regimens. We used human glioblastoma GBM 8401/luc2 cell-generated xenograft mice model for in vivo experiments, and our results indicated that BDMC at both doses (30 and $60 \mathrm{mg} / \mathrm{kg}$ ) treatment significantly suppressed the tumor volume and weight of GBM 8401/luc2-cell-generated xenograft mice in vivo (Figure 3). Furthermore, BDMC elevated the active form of caspase-3 and pro-apoptotic protein BAX and decreased the anti-apoptotic protein Bcl-2 and XIAP (Figure 6).

The preclinical model, which is based on patient-derived tumor xenografts, has new insight into many clinical fields; thus, many authors have recognized immunodeficient animals such as athymic rats and mice to be used to prevent tissue loss caused by acute rejection to establish patient-derived tumor xenografts models. It is well documented that athymic nude mice were suitable for examining natural compounds or anticancer drugs that inhibit cancer cell-generated xenograft mice model in vivo [32]. Recently, in our earlier studies, we established GBM 8401/luc2 cell xenograft tumor growth in athymic BALB/c $\mathrm{nu} / \mathrm{nu}$ nude mice for evaluating whether or not compounds such as BITC and PEITC reduced tumor in vivo $[33,34]$. A similar animal model (GBM 8401/luc2 cell xenograft mice) was also used in this study. The body weights of tumor-bearing mice in all groups were simultaneously recorded. The BDMC-treated and control group did not show differences in the body weight during treatment period, indicating no systemic toxicity of BDMC (Figure 3).

Results indicated that significant difference of tumor size was observed between BDMC-treated and control groups. The control group showed a progressive increase in tumor volume, while tumors in both BDMC-treated groups displayed growth retardation. BDMC decreased tumor volume and weight in GBM 8401/luc2 cell xenograft mice, and a higher dose $(60 \mathrm{mg} / \mathrm{kg})$ of BDMC treatment has a higher inhibition than that of a lower dose (30 mg/kg) (Figure 4). Furthermore, we also used this CMV-derived luc2 reporter gene to monitor the tumor growth of GBM 8401/luc2-bearing tumor mice. As shown in BLI results from each group of mice, a relatively cold signal was found in the BDMC-treated groups on the color-coded map (Figure 5A). The total photon flux of the control group was two to four times more than BDMC-treated mice (Figure 5B). Significant living cell signal suppression was found in higher dosage $(60 \mathrm{mg} / \mathrm{kg})$ of BDMC-treated mice since day 7. $\mathrm{BDMC}$ treatment may reduce the living cell number within the tumor area. This finding is consistent with the results of tumor size and weights (Figure 4).

It is recognized that the compounds could be suitable as tumor-inhibiting agents with the ability to simultaneously block multiple hallmarks of tumor capabilities [35], specifically in inducing cancer cell apoptosis without causing cellular toxicity. In this study, we isolated the liver from each mouse of each group; livers were performed with H\&E staining, and results show that BDMC did not induce toxicity in animals (Figure 3A). If an agent can alter protein expression or simultaneously block multiple cancer-associated pathways, it will be developed for a viable approach to inhibit tumor growth and progression. Therefore, to further confirm BDMC displayed in tumor growth retardation compared to control groups, herein, we also took tumor samples from each mouse of each group for examining apoptosis-associated protein expression by BDMC treatment. Our results indicated that tumor tissues of mice exposed to BDMC showed relatively lower levels of anti-apoptotic proteins (Bcl-2) and XIAP when compared to the control group. However, tumor tissues of mice exposed to BDMC showed higher levels of cleaved caspase-3 and BAX (pro-apoptotic protein) (Figure 6). Significant differences were observed between BDMC-treated and control groups $(p<0.01)$, clearly indicating that BDMC is considerably effective in inducing apoptosis and inhibiting tumor growth (Figure 6).

Bcl-2 family proteins, which are divided into anti-apoptotic proteins, such as Bcl-2, and pro-apoptotic proteins such as BAX, are involved in cell apoptosis. The decreases of the $\mathrm{Bcl}-2 / \mathrm{BAX}$ ratio lead to the release of cytochrome $\mathrm{C}$ from the mitochondria for 
activating the mitochondrial-dependent caspase cascade and then inducing apoptotic cell death $[36,37]$. In the mitochondrial membrane, BAX is a constituent of the ion channel involved in the loss of $\Delta \psi \mathrm{m} . \mathrm{Bcl}-2$ is an oncogene with multiple anti-apoptotic functions, and it combines with BAX to prevent the formation of the ion channel [38]. Therefore, it is well documented that the Bcl-2/BAX ratio acts as a critical role in the induction of apoptosis. In the present study, BDMC significantly inhibited the tumor growth of GBM 8401 xenograft mice in vivo via upregulating the expression of BAX (pro-apoptotic factor) and caspase-3 and downregulating the expression of Bcl-2 (anti-apoptotic factor) and XIAP in tumor tissues. It is well known that increasing cell apoptosis of the tumor in the therapeutic process may result in a reduction of tumor size [39].

The apoptosis caspases (a cysteine protease family) and the apoptosis suppressor gene Bcl-2 (Bcl-2 family) both play important roles in the apoptosis process. Caspase can activate the whole protease family after itself activation $[40,41]$. The caspases- 3 is one of the caspase family proteins and exerts a vital apoptosis effector, which can be activated by the upstream initiating subsystem, or via caspase-9 to make the cell biochemical changes and morphological changes, and then finally lead to cell apoptosis [42,43]. The X-linked inhibitor of apoptosis (XIAP), a potent inhibitor of cell death, exerts the ability to directly suppress the caspases [44] when the interaction of caspase 9 and 3 allows the XIAP to block the caspases activities efficiently, preventing a proteolytic cascade. Recently, literature has reported higher expressions of XIAP and Bcl-2 in the GBM samples than that of normal brain samples and XIAP involved in apoptosis resistance [45]; thus, XIAP has been recognized to be the best way to develop new target therapy strategies among GBM patients.

In conclusion, overall, in the present study, in vivo experiments using a GBM 8401/luc2 cell xenograft tumor growth in athymic BALB/c nu/nu nude mice model showed that BDMC treatment significantly decreased the tumor volume and weight compared to control groups. Moreover, the body weight and liver tissues in H\&E staining from each mouse of each group showed that the BDMC treatment did not cause significant systemic toxicity to the mice. Tumor tissues were stained with apoptosis-associated antibody, which indicated that BDMC-induced cell apoptosis. Thus, we suggested that BDMC may act as an effective chemosensitizer against GBM patients in the future.

\section{Materials and Methods}

\subsection{Test Compound, Reagents, Antibodies, and Culture Medium}

Bisdemethoxycurcumin (BDMC) was purchased from ChemFaces (Wuhan, Hubei, China) and dissolved in dimethyl sulfoxide (DMSO) as $150 \mathrm{mg} / \mathrm{mL}$ stock (Sigma Chemical Co., St. Louis, MI, USA). Roswell Park Memorial Institute (RPMI) 1640 Medium, fetal bovine serum (FBS), and penicillin-streptomycin were purchased from Life Technologies (Carlsbad, CA, USA). JetPEI ${ }^{\mathrm{TM}}$ transfection reagent was obtained from Polyplus Transfection (Illkirch, Bas-Rhin, France). D-luciferin and pGL4.50 luciferase reporter (pGL4.50[luc2/CMV]) vector were obtained from Promega (Madison, WI, USA). Hygromycin B was obtained from Santa Cruz Biotechnology (Santa Cruz, CA, USA). Primary monoclonal antibody for immunohistochemistry staining was listed as follows: anti-Bcl-2 (1:300 dilution; Cell signaling, Danvers, MA, USA), anti-XIAP (1:300 dilution; Elabscience Biotechnology Inc., Houston, TX, USA), anti-cleaved caspase-3 (1:300 dilution; Cell signaling), and anti-BAX antibodies (1:300 dilution; Rosemont, IL, USA).

\subsection{Cell Culture of GBM 8401 Cells}

Human brain glioblastoma cell line (GBM 8401) was obtained from The Food Industry Research and Development Institute (Hsinchu, Taiwan) and was cultured in RPMI-1640 supplemented with $10 \% \mathrm{FBS}, 100 \mathrm{U} / \mathrm{mL}$ penicillin, and $100 \mu \mathrm{g} / \mathrm{mL}$ streptomycin in $5 \% \mathrm{CO}_{2}$ humidified incubators at $37^{\circ} \mathrm{C}[34]$. 


\subsection{Cell Culture, Transfection, and Stable Clone Selection}

Human glioblastoma GBM 8401 cells were cultured in the 10-cm dish with RPMI1640 supplemented with $10 \% \mathrm{FBS}, 100 \mathrm{U} / \mathrm{mL}$ penicillin, and $100 \mu \mathrm{g} / \mathrm{mL}$ streptomycin, in $5 \% \mathrm{CO}_{2}$ humidified incubators at $37^{\circ} \mathrm{C}$ [34]. Plasmid transfection and stable clone selection protocol were described in our previous studies $[46,47]$. In brief, pGL4.50 luciferase reporter (pGL4.50[luc2/CMV]) plasmid and JetPEI ${ }^{\mathrm{TM}}$ transfection reagents mixture was added to GBM 8401 cells overnight. Then, $200 \mu \mathrm{g} / \mathrm{mL}$ hygromycin B was used to select and maintain the stability of luc2 expression in GBM 8401 cells. Luc2 signaling was acquired by IVIS 200 Imaging System (Xenogen, Alameda, CA, USA). This stable luc2 reporter gene cell was defined as GBM 8401/luc2.

\subsection{Measurements of Cytotoxicity}

Cell cytotoxicity (cell viability) was determined by MTT assay. GBM 8401/luc2 cells $\left(1 \times 10^{4}\right.$ cells/well) were placed in 96-well plates for $24 \mathrm{~h}$ and then were treated with 0 , $10,15,20,25,30,35,40,45$, and $50 \mu \mathrm{M}$ of BDMC for $48 \mathrm{~h}$. In brief, a $10 \mu \mathrm{L}$ solution ( $5 \mathrm{mg} / \mathrm{mL}$ MTT) was added to each well for $4 \mathrm{~h}$ at $37^{\circ} \mathrm{C}$; discarded supernatant, followed a $100 \mu \mathrm{L}$ DMSO, was added to well for dissolving the purple formazan crystalas described previously [48]. All treatment concentrations were performed in three independent tests.

\subsection{Annexin V/PI Staining for Cell Apoptosis Assay}

The percentage of cell apoptosis was evaluated by using the Annexin V-FITC/PI Apoptosis Detection kit followed the guideline from the manufacturer. GBM 8401/luc2 cells were seeded into 24-well tissue culture plates $\left(1 \times 10^{5}\right.$ cells/well) for $24 \mathrm{~h}$ and were treated with $0,20,25$, and $30 \mu \mathrm{M}$ of BDMC for $48 \mathrm{~h}$. Following treatment, the cells were collected, washed with PBS, and resuspended in $200 \mu \mathrm{L}$ Annexin V binding buffer and were incubated with Annexin V-FITC/PI in the dark for $15 \mathrm{~min}$ and samples were analyzed of cell apoptosis by flow cytometry (BD FACSCanto, Franklin Lakes, NJ, USA) as described previously [49].

\subsection{Cytoxicity of Cotreatment BDMC with Caspase-3 or MMP Inhibitor}

GBM 8401/luc2 cells $\left(1 \times 10^{4}\right.$ cells/well $)$ were placed in 96-well plates for $24 \mathrm{~h}$ and then were pretreated with Z-DEVD-FMK (caspase-3 inhibitor) $(25 \mu \mathrm{M})$ or inhibitor of mitochondria membrane potential (cyclosporin A) $(1 \mu \mathrm{M})$ and were treated with 0 and $25 \mu \mathrm{M}$ of BDMC for $48 \mathrm{~h}$. Cells proliferation (viability) was measured by MTT assay as described previously [48]. All experiments were done in triplicate.

\subsection{Western Blotting}

GBM 8401/luc2 cells $\left(1.5 \times 10^{6}\right.$ cells/dish) were placed in 10-cm dish and pretreated with Z-DEVD-FMK (caspase-3 inhibitor) $(25 \mu \mathrm{M})$ or inhibitor of mitochondria membrane potential (cyclosporin A) $(1 \mu \mathrm{M})$ and were treated with 0 and $25 \mu \mathrm{M}$ of BDMC for $48 \mathrm{~h}$. All cells from each treatment were collected, extracted, and quantitated total proteins using the Bio-Rad Protein Assay kit (Bio-Rad, Hercules, CA, USA). A $30 \mu \mathrm{g}$ of sample was separated by $10 \%$ sodium dodecyl sulfate-polyacrylamide gel electrophoresis and was transferred onto polyvinylidene difluoride membranes (Millipore, Billerica, MA, USA). All membranes were incubated with primary antibodies (ant-pro-caspase-3, -active-caspase-3, -Bcl-2, -Bax, -cytochrome c, and -AIF) overnight, washed, and then incubated with peroxidase-labelled secondary antibody. The membranes were washed and incubated in ECL western blot analysis substrate (Bio-Rad, Hercules, CA, USA), and the protein bands were visualized and photographed as described previously [48]. All results were obtained from three independent experiments.

\subsection{Establishment of Glioblastoma Xenograft Bearing Mice and Treatments}

Athymic BALB/c nu/nu (NUDE mice), 22-28 g in weight and 6-8 weeks of age, were obtained from the National Laboratory Animal Center (Taipei, Taiwan). Mice were 
maintained at a constant temperature of $25 \pm 1{ }^{\circ} \mathrm{C}$ in $55 \%$ humidity with a $12 \mathrm{~h}$ light/dark cycle and were regularly provided with food and water. All animal experiment procedures had been approved by the institutional animal care and use committee (IACUC) in China Medical University, Taichung, Taiwan (ID: CMU2019-204). GBM 8401/luc2 cells $\left(1 \times 10^{7}\right.$ cells in $150 \mu \mathrm{L}$ serum-free RPMI-1640 and Matrigel (2:1) mixture) were subcutaneously injected into the right flanks of the mice, and two weeks later, the mice were successfully induced as a model of glioblastoma [33,50]. A total of 12 mice were randomly divided into three groups $\left(n=4\right.$ each) when the tumor reached $100 \mathrm{~mm}^{3}$ and subsequently received different treatments as described below. Group I mice served as control and were treated with $0.1 \%$ DMSO, which dissolved in $100 \mu \mathrm{L}$ double-distilled water (DDW) for 21 days. Group II and III were treated with $30 \mathrm{mg} / \mathrm{kg}$ and $60 \mathrm{mg} / \mathrm{kg}$ BDMC for 21 days, respectively (both dissolved in $100 \mu \mathrm{L}$ DDW) (Figure 2).

\subsection{Treatment Efficacy Evaluation and Animal Bioluminescent Imaging}

Mice tumor size and body weight were evaluated by caliper (Mitutoyo America, Aurora, IL, USA) every three days. Tumor volumes were measured by the formula: volume $\left(\mathrm{mm}^{3}\right)=(0.523) \times$ length $(\mathrm{mm}) \times \mathrm{width}^{2}(\mathrm{~mm})$ [33]. In vivo bioluminescent imaging (BLI) was performed on days $0,7,14$, and 21 after BDMC treatment. Mouse tumor from each group was isolated and weighed on day 21 and then fixed for further H\&E and IHC staining (Figure 2). $100 \mu \mathrm{L}$ D-luciferin (150 mg/kg dissolved in PBS) was injected into the peritoneal by a 30-gauge needle 15 min before image acquisition. After 15 min, mice were anesthetized with $1-3 \%$ isoflurane and scanned by IVIS ${ }^{\circledR}$ Lumina LT Series III (Bruker, Billerica, MA, USA) for $3 \mathrm{~min}$. The signal intensities of BLI were quantified by using Living Image software (Version 2.20, Xenogen, Alameda, CA, USA).

\subsection{Hematoxylin and Eosin (HEE) and Immunohistochemistry (IHC)}

At the end of treatment, liver and tumor tissues were isolated and fixed in $10 \%$ neutral buffered formalin for $24 \mathrm{~h}$ and embedded in paraffin. Paraffin-embedded liver tissues were sliced at $5 \mu \mathrm{m}$, deparaffinized, rehydrated, and stained with hematoxylin and eosin (H\&E) [51]. Paraffin-embedded tumor tissues were also sliced at $5 \mu \mathrm{m}$; deparaffinized; subjected to antigen retrieval; and stained with anti-Bcl-2, anti-XIAP, anti-cleaved caspase-3, and anti-BAX primary antibodies at 1:300 concentrations. After $24 \mathrm{~h}$ antibodies incubation at $4{ }^{\circ} \mathrm{C}$, secondary antibodies were incubated for another $1 \mathrm{~h}$ then washed and incubated with Horseradish Peroxidase Streptavidin (HRP Streptavidin) as protocol described in EMD Millipore's IHC Select ${ }^{\circledR}$ kit (EMD Millipore, Billerica, MA, USA) [52]. Sections were finally rinsed by distilled water, dehydrated, and mounted with mounting medium for Nikon ECLIPSE Ti-U light microscope evaluation (Nikon Instruments Inc., Melville, NY, USA). Image of IHC was quantified by ImageJ software version 1.50 (National Institutes of Health, Bethesda, MD, USA).

\subsection{Statistical Analysis}

All data represent as mean \pm S.D. In vitro study, a significant difference was compared by one-way ANOVA. In vivo study, a significant difference between the BDMC $60 \mathrm{mg} / \mathrm{kg}-$ treated, BDMC $30 \mathrm{mg} / \mathrm{kg}$-treated and control groups were compared by Student's $t$-test. In all figures, significant difference was presented as $\mathrm{a}^{1} p<0.05$ or $\mathrm{a}^{2} p<0.01 \mathrm{vs}$. control; and $\mathrm{b}^{1} p<0.05$ or $\mathrm{b}^{2} p<0.01$ vs. BDMC-treated.

Author Contributions: T.-C.H., F.-T.H. and R.S.-C.W. conceived the project; T.-C.H. performed the experiments; S.-F.P., F.-S.C., K.-W.L., J.-L.Y. and A.-C.H. analyzed the bioinformatics analyses; F.-T.H. and R.S.-C.W. wrote the manuscript. All authors have read and agreed to the published version of the manuscript.

Funding: This study was supported by a grant from the Ministry of Science and Technology, Taipei, Taiwan (grant number: MOST 109-2314-B-039-021-MY3).

Institutional Review Board Statement: Not applicable. 
Informed Consent Statement: The animal study protocol was approved by the Institutional Review Board China Medical University, Taichung, Taiwan (ID: CMU2019-204).

Data Availability Statement: Data available on request from corresponding author.

Acknowledgments: Experiments and data analysis were performed in part through the use of the Medical Research Core Facilities Center, Office of Research \& Development at China Medical University, Taichung, Taiwan, ROC.

Conflicts of Interest: We wish to confirm that there are no known conflicts of interest associated with this publication and there has been no significant financial support for this work that could have influenced its outcome.

\section{References}

1. Hess, K.R.; Broglio, K.R.; Bondy, M.L. Adult glioma incidence trends in the United States, 1977-2000. Cancer 2004, 101, 2293-2299. [CrossRef] [PubMed]

2. Adamson, C.; Kanu, O.O.; Mehta, A.I.; Di, C.; Lin, N.; Mattox, A.K.; Bigner, D.D. Glioblastoma multiforme: A review of where we have been and where we are going. Expert Opin. Investig. Drugs 2009, 18, 1061-1083. [CrossRef]

3. Louis, D.N.; Ohgaki, H.; Wiestler, O.D.; Cavenee, W.K.; Burger, P.C.; Jouvet, A.; Scheithauer, B.W.; Kleihues, P. The 2007 WHO classification of tumours of the central nervous system. Acta Neuropathol. 2007, 114, 97-109. [CrossRef] [PubMed]

4. Brown, J.M. Vasculogenesis: A crucial player in the resistance of solid tumours to radiotherapy. Br. J. Radiol. 2014, 87, 20130686. [CrossRef] [PubMed]

5. Stupp, R.; Hegi, M.E.; Mason, W.P.; Van Den Bent, M.J.; Taphoorn, M.J.; Janzer, R.C.; Ludwin, S.K.; Allgeier, A.; Fisher, B.; Belanger, K.; et al. Effects of radiotherapy with concomitant and adjuvant temozolomide versus radiotherapy alone on survival in glioblastoma in a randomised phase III study: 5-year analysis of the EORTC-NCIC trial. Lancet Oncol. 2009, 10, 459-466. [CrossRef]

6. Yamanaka, R.; Hayano, A.; Kanayama, T. Radiation-induced gliomas: A comprehensive review and meta-analysis. Neurosurg. Rev. 2018, 41, 719-731. [CrossRef]

7. Brandes, A.A.; Tosoni, A.; Franceschi, E.; Sotti, G.; Frezza, G.; Amistà, P.; Morandi, L.; Spagnolli, F.; Ermani, M. Recurrence pattern after temozolomide concomitant with and adjuvant to radiotherapy in newly diagnosed patients with glioblastoma: Correlation With MGMT promoter methylation status. J. Clin. Oncol. 2009, 27, 1275-1279. [CrossRef]

8. Vallejo, M.J.; Salazar, L.; Grijalva, M. Oxidative Stress Modulation and ROS-Mediated Toxicity in Cancer: A Review on In Vitro Models for Plant-Derived Compounds. Oxid. Med. Cell. Longev. 2017, 2017, 4586068. [CrossRef]

9. Chikara, S.; Nagaprashantha, L.D.; Singhal, J.; Horne, D.; Awasthi, S.; Singhal, S.S. Oxidative stress and dietary phytochemicals: Role in cancer chemoprevention and treatment. Cancer Lett. 2018, 413, 122-134. [CrossRef]

10. Gavamukulya, Y.; Wamunyokoli, F.; El-Shemy, H.A. Annona muricata: Is the natural therapy to most disease conditions including cancer growing in our backyard? A systematic review of its research history and future prospects. Asian Pac. J. Trop. Med. 2017, 10, 835-848. [CrossRef]

11. Kapinova, A.; Stefanicka, P.; Kubatka, P.; Zubor, P.; Uramova, S.; Kello, M.; Mojzis, J.; Blahutova, D.; Qaradakhi, T.; Zulli, A.; et al. Are plant-based functional foods better choice against cancer than single phytochemicals? A critical review of current breast cancer research. Biomed. Pharmacother. 2017, 96, 1465-1477. [CrossRef] [PubMed]

12. Rayan, A.; Raiyn, J.; Falah, M. Nature is the best source of anticancer drugs: Indexing natural products for their anticancer bioactivity. PLoS ONE 2017, 12, e0187925. [CrossRef] [PubMed]

13. Chen, H.W.; Huang, H.C. Effect of curcumin on cell cycle progression and apoptosis in vascular smooth muscle cells. Br. J. Pharmacol. 1998, 124, 1029-1040. [CrossRef]

14. Orona-Ortiz, A.; Velázquez-Moyado, J.A.; Pineda-Peña, E.A.; Balderas-López, J.L.; Tavares Carvalho, J.C.; Navarrete, A. Effect of the proportion of curcuminoids on the gastroprotective action of Curcuma longa L. in rats. Nat. Prod. Res. 2019, 35, 1903-1908. [CrossRef] [PubMed]

15. Hongtao, C.; Youling, F.; Fang, H.; Huihua, P.; Jiying, Z.; Jun, Z. Curcumin alleviates ischemia reperfusion-induced late kidney fibrosis through the APPL1/Akt signaling pathway. J. Cell. Physiol. 2018, 233, 8588-8596. [CrossRef]

16. Paul, M.; Manikanta, K.; Hemshekhar, M.; Sundaram, M.S.; Naveen, S.; Ramesh, T.N.; Kemparaju, K.; Girish, K.S. Bisdemethoxycurcumin promotes apoptosis in human platelets via activation of ERK signaling pathway. Toxicol. In Vitro 2020, 63, 104743. [CrossRef]

17. Huang, T.Y.; Peng, S.F.; Huang, Y.P.; Tsai, C.H.; Tsai, F.J.; Huang, C.Y.; Tang, C.H.; Yang, J.S.; Hsu, Y.M.; Yin, M.C.; et al. Combinational treatment of all-trans retinoic acid (ATRA) and bisdemethoxycurcumin (BDMC)-induced apoptosis in liver cancer Hep3B cells. J. Food Biochem. 2020, 44, e13122. [CrossRef]

18. Huang, C.; Lu, H.F.; Chen, Y.H.; Chen, J.C.; Chou, W.H.; Huang, H.C. Curcumin, demethoxycurcumin, and bisdemethoxycurcumin induced caspase-dependent and -independent apoptosis via Smad or Akt signaling pathways in HOS cells. BMC Complement. Med. Ther. 2020, 20, 68. [CrossRef] 
19. Li, X.; Huo, C.; Xiao, Y.; Xu, R.; Liu, Y.; Jia, X.; Wang, X. Bisdemethoxycurcumin Protection of Cardiomyocyte Mainly Depends on Nrf2/HO-1 Activation Mediated by the PI3K/AKT Pathway. Chem. Res. Toxicol. 2019, 32, 1871-1879. [CrossRef]

20. Lai, C.S.; Chen, Y.Y.; Lee, P.S.; Kalyanam, N.; Ho, C.T.; Liou, W.S.; Yu, R.C.; Pan, M.H. Bisdemethoxycurcumin Inhibits Adipogenesis in 3T3-L1 Preadipocytes and Suppresses Obesity in High-Fat Diet-Fed C57BL/6 Mice. J. Agric. Food Chem. 2016, 64, 821-830. [CrossRef]

21. Jin, F.; Chen, X.; Yan, H.; Xu, Z.; Yang, B.; Luo, P.; He, Q. Bisdemethoxycurcumin attenuates cisplatin-induced renal injury through anti-apoptosis, anti-oxidant and anti-inflammatory. Eur. J. Pharmacol. 2020, 874, 173026. [CrossRef]

22. Dützmann, S.; Schiborr, C.; Kocher, A.; Pilatus, U.; Hattingen, E.; Weissenberger, J.; Geßler, F.; Quick-Weller, J.; Franz, K.; Seifert, V.; et al. Intratumoral Concentrations and Effects of Orally Administered Micellar Curcuminoids in Glioblastoma Patients. Nutr. Cancer 2016, 68, 943-948. [CrossRef]

23. Yasui, L.; Owens, K. Necrosis is not induced by gadolinium neutron capture in glioblastoma multiforme cells. Int. J. Radiat. Biol. 2012, 88, 980-990. [CrossRef]

24. Fedrigo, C.A.; Grivicich, I.; Schunemann, D.P.; Chemale, I.M.; dos Santos, D.; Jacovas, T.; Boschetti, P.S.; Jotz, G.P.; Braga Filho, A.; da Rocha, A.B. Radioresistance of human glioma spheroids and expression of HSP70, p53 and EGFr. Radiat. Oncol. $2011,6,156$. [CrossRef]

25. Filippi-Chiela, E.C.; Villodre, E.S.; Zamin, L.L.; Lenz, G. Autophagy interplay with apoptosis and cell cycle regulation in the growth inhibiting effect of resveratrol in glioma cells. PLOS ONE 2011, 6, e20849. [CrossRef] [PubMed]

26. Sun, J.; Wei, Q.; Zhou, Y.; Wang, J.; Liu, Q.; Xu, H. A systematic analysis of FDA-approved anticancer drugs. BMC Syst. Biol. 2017, 11 (Suppl. 5), 87. [CrossRef]

27. Emery, I.F.; Gopalan, A.; Wood, S.; Chow, K.H.; Battelli, C.; George, J.; Blaszyk, H.; Florman, J.; Yun, K. Expression and function of ABCG2 and XIAP in glioblastomas. J. Neurooncol. 2017, 133, 47-57. [CrossRef] [PubMed]

28. Vellanki, S.H.; Grabrucker, A.; Liebau, S.; Proepper, C.; Eramo, A.; Braun, V.; Boeckers, T.; Debatin, K.M.; Fulda, S. Small-molecule XIAP inhibitors enhance gamma-irradiation-induced apoptosis in glioblastoma. Neoplasia 2009, 11, 743-752. [CrossRef] [PubMed]

29. Lee, F.A.; Zee, B.C.; Cheung, F.Y.; Kwong, P.; Chiang, C.L.; Leung, K.C.; Siu, S.W.; Lee, C.; Lai, M.; Kwok, C.; et al. Randomized Phase II Study of the X-linked Inhibitor of Apoptosis (XIAP) Antisense AEG35156 in Combination With Sorafenib in Patients With Advanced Hepatocellular Carcinoma (HCC). Am. J. Clin. Oncol. 2016, 39, 609-613. [CrossRef] [PubMed]

30. Liu, P.; Zhao, H.; Luo, Y. Anti-Aging Implications of Astragalus Membranaceus (Huangqi): A Well-Known Chinese Tonic. Aging Dis. 2017, 8, 868-886. [CrossRef]

31. Luo, S.M.; Wu, Y.P.; Huang, L.C.; Huang, S.M.; Hueng, D.Y. The anti-cancer effect of four Curcumin Analogues on human glioma cells. Onco. Targets Ther. 2021, 14, 4345-4359. [CrossRef]

32. Mattern, J.; Bak, M.; Hahn, E.W.; Volm, M. Human tumor xenografts as model for drug testing. Cancer Metastasis Rev. 1988, 7 , 263-284. [CrossRef]

33. Ma, Y.S.; Lin, J.J.; Lin, C.C.; Lien, J.C.; Peng, S.F.; Fan, M.J.; Hsu, F.T.; Chung, J.G. Benzyl isothiocyanate inhibits human brain glioblastoma multiforme GBM 8401 cell xenograft tumor in nude mice in vivo. Environ. Toxicol. 2018, 33, 1097-1104. [CrossRef] [PubMed]

34. Chou, Y.C.; Chang, M.Y.; Lee, H.T.; Shen, C.C.; Harnod, T.; Liang, Y.J.; Wu, R.S.; Lai, K.C.; Hsu, F.T.; Chung, J.G. Phenethyl Isothiocyanate Inhibits In Vivo Growth of Xenograft Tumors of Human Glioblastoma Cells. Molecules 2018, 23, 2305. [CrossRef] [PubMed]

35. Hanahan, D.; Weinberg, R.A. The hallmarks of cancer. Cell 2000, 100, 57-70. [CrossRef]

36. Lan, C.H.; Sheng, J.Q.; Fang, D.C.; Meng, Q.Z.; Fan, L.L.; Huang, Z.R. Involvement of VDAC1 and Bcl-2 family of proteins in VacA-induced cytochrome c release and apoptosis of gastric epithelial carcinoma cells. J. Dig. Dis. 2010, 11, 43-49. [CrossRef] [PubMed]

37. Li, M.; Wan, G.; Yu, H.; Xiong, W. High-intensity focused ultrasound inhibits invasion and metastasis of colon cancer cells by enhancing microRNA-124-mediated suppression of STAT3. FEBS Open Biol. 2019, 9, 1128-1136. [CrossRef]

38. Wong, R.S. Apoptosis in cancer: From pathogenesis to treatment. J. Exp. Clin. Cancer Res. 2011, 30, 87. [CrossRef]

39. Ray, S.K.; Patel, S.J.; Welsh, C.T.; Wilford, G.G.; Hogan, E.L.; Banik, N.L. Molecular evidence of apoptotic death in malignant brain tumors including glioblastoma multiforme: Upregulation of calpain and caspase-3. J. Neurosci. Res. 2002, 69, 197-206. [CrossRef] [PubMed]

40. Huang, K.H.; Fang, W.L.; Li, A.F.; Liang, P.H.; Wu, C.W.; Shyr, Y.M.; Yang, M.H. Caspase-3, a key apoptotic protein, as a prognostic marker in gastric cancer after curative surgery. Int. J. Surg. 2018, 52, 258-263. [CrossRef]

41. Clark, A.C. Caspase Allostery and Conformational Selection. Chem. Rev. 2016, 116, 6666-6706. [CrossRef]

42. Garrido, C.; Galluzzi, L.; Brunet, M.; Puig, P.E.; Didelot, C.; Kroemer, G. Mechanisms of cytochrome c release from mitochondria. Cell Death Differ. 2006, 13, 1423-1433. [CrossRef]

43. Cain, K. Chemical-induced apoptosis: Formation of the Apaf-1 apoptosome. Drug Metab. Rev. 2003, 35, 337-363. [CrossRef] [PubMed]

44. Salvesen, G.S.; Duckett, C.S. IAP proteins: Blocking the road to death's door. Nat. Rev. Mol. Cell Biol. 2002, 3, 401-410. [CrossRef] [PubMed] 
45. Tirapelli, D.; Lustosa, I.L.; Menezes, S.B.; Franco, I.M.; Rodrigues, A.R.; Peria, F.M.; Marinho, A.; Serafini, L.N.; Carlotti, C.G., Jr.; Tirapelli, L.F. High expression of XIAP and Bcl-2 may inhibit programmed cell death in glioblastomas. Arq. Neuropsiquiatr. 2017, 75, 875-880. [CrossRef]

46. Chen, W.T.; Chen, Y.K.; Lin, S.S.; Hsu, F.T. Hyperforin Suppresses Tumor Growth and NF-kappaB-mediated Anti-apoptotic and Invasive Potential of Non-small Cell Lung Cancer. Anticancer Res. 2018, 38, 2161-2167. [PubMed]

47. Weng, M.C.; Wang, M.H.; Tsai, J.J.; Kuo, Y.C.; Liu, Y.C.; Hsu, F.T.; Wang, H.E. Regorafenib inhibits tumor progression through suppression of ERK/NF-kappaB activation in hepatocellular carcinoma bearing mice. Biosci. Rep. 2018, 38, BSR20171264. [CrossRef]

48. Maraming, P.; Klaynongsruang, S.; Boonsiri, P.; Peng, S.F.; Daduang, S.; Rungsa, P.; Tavichakorntrakool, R.; Chung, J.G.; Daduang, J. Anti-metastatic Effects of Cationic KT2 Peptide (a Lysine/Tryptophan-rich Peptide) on Human Melanoma A375.S2 Cells. In Vivo 2021, 35, 215-227. [CrossRef] [PubMed]

49. Huang, Y.C.; Kuo, C.L.; Lu, K.W.; Lin, J.J.; Yang, J.L.; Wu, R.S.; Wu, P.P.; Chung, J.G. 18alpha-Glycyrrhetinic Acid Induces Apoptosis of HL-60 Human Leukemia Cells through Caspases- and Mitochondria-Dependent Signaling Pathways. Molecules 2016, 21, 872. [CrossRef] [PubMed]

50. Hsu, F.T.; Chiang, I.T.; Kuo, Y.C.; Hsia, T.C.; Lin, C.C.; Liu, Y.C.; Chung, J.G. Amentoflavone Effectively Blocked the Tumor Progression of Glioblastoma via Suppression of ERK/NF-kappa B Signaling Pathway. Am. J. Chin. Med. 2019, 47, 913-931. [CrossRef] [PubMed]

51. Chiu, W.C.; Yang, H.H.; Chiang, S.C.; Chou, Y.X.; Yang, H.T. Auricularia polytricha aqueous extract supplementation decreases hepatic lipid accumulation and improves antioxidative status in animal model of nonalcoholic fatty liver. BioMedicine 2014, 4, 12. [CrossRef] [PubMed]

52. Tsai, J.J.; Hsu, F.T.; Pan, P.J.; Chen, C.W.; Kuo, Y.C. Amentoflavone Enhances the Therapeutic Efficacy of Sorafenib by Inhibiting Anti-apoptotic Potential and Potentiating Apoptosis in Hepatocellular Carcinoma In Vivo. Anticancer Res. 2018, 38, 2119-2125. [PubMed] 